\title{
RUINED SETTLEMENTS AND NEW GARDENS: GENDER AND SOIL-RIPENING AMONG KURANKO FARMERS IN THE FOREST-SAVANNA TRANSITION ZONE
}

\section{Melissa Leach and James Fairhead}

\section{INTRODUCTION'}

Gardening is often seen as a women's activity, a relatively unchanging aspect of the division of labour, and it has been invoked in some ecofeminisminfluenced discussions toembody women's supposed sustenance-oriented, caring relationship with 'nature' (Mies and Shiva 1993; Dankelman and Davidson 1988). For Kuranko farmers in Guinea, West Africa, gardens are indeed central to gender-environment relations, but in ways which fail to conform to these images and are far from natural and timeless.

This article examines how, as a particular sort of field-soil-vegetation complex, Kuranko 'gardens' provide the locus of a set of indigenous agro-ecological techniques and understandings which have been applied in changing ways across the landscape during the last century. Who gardens, where and how, have altered with changing patterns of gendered resource use: of women's and men's work, of rights and control over land and labour, and of claims to income and products, in the context of broader economic and social changes. By altering the prevalence of this field-soil-vegetation complex within overall land use patterns, these changes have had a significant impact on vegetation cover. In the process, gendered work and knowledge have come to acquire new meanings (cf. Carney and Watts 1991); conceptual links between women and gardens have been reworked, and differentiated experiences of the complicated history of gardened places engender different opinions about why land types are fertile and what determines entitlement to use them.

This case provides a powerful illustration of how changing gender relations can shape, as well as be shaped by, patterns of environmental change. As recent work in feminist political ecology shows, both the micro-political economy of gendered resource use (Leach 1991) and the wider political-economy it articulates with are important in accounting for

\footnotetext{
${ }^{1}$ This article is the result of our joint and equal co-authorship. It is based on research funded by ESCOR of the Overseas Development Administration, whom we gratefully thank. Opinions represented here are, however, the authors' own, not those of the ODA. Many thanks are also due to our Guinean co-researchers Dominique
}

environmental outcomes. But as we emphasize here, ecology also deserves close attention (cf. Watts and Peet 1993) since ecological particularities strongly affect how landscapes and sites respond to use.

In the ecological literature, the impact of increasing land use on forest cover in the forest-savanna transition zone is commonly assumed to be negative or, at best, benign within limits (Furley et al. 1992). Previous analysts of Kissidougou prefecture in this zone of Guinea (Figure 1) have been no exception (Adam 1948; République de Guinée 1988). Here, the duration and depth of the dry season make the presence of humid forest marginal, especially in the presence of fire, rendering it prone to savannization. In such marginal climatic conditions appropriate soil-water and fertility conditions are now recognized as key factors in permitting forest establishment, and hence in determining forest-savanna distribution patterns (Furley et al. 1992; Morgan and Moss 1965; Avenard et al. 1974). But while it is commonly argued that farmers encourage soil and vegetation degradation, the possibility that they enrich and improve soils, and hence enable and encourage improved fallows, has hardly been addressed. Yet for Kuranko, the establishment of forest patches in savanna is a central part of land management (Leach and Fairhead 1994), and as this article shows, gardening is a central process in this.

\section{THE AGRO-ECOLOGY OF TOMBONDU}

However short the walk, a traveller within the Kissidougou region is likely to pass several sites which were once inhabited, be they long-abandoned villages, hamlets or farm camps. The soils of these ruins (tombon) are known as tombondu ( $d u=$ soil/ land) and are particularly appreciated for farming, enriched as they have been over long years of habitation from the ash of wood fires; the excreta of tethered cattle, other domestic animals and poultry, and the

Millimouno and Marie Kamano, to the villagers of Sandaya and to our collaborating institutions: the Ministère de l'Enseignment Superieur; the Direction National des Forêts et de la Chasse, and Projet DERIK, Kissidougou. 


\section{Figure 1: Kissidougou Prefecture in the Forest-Savanna Mosaic Zone of West Africa}

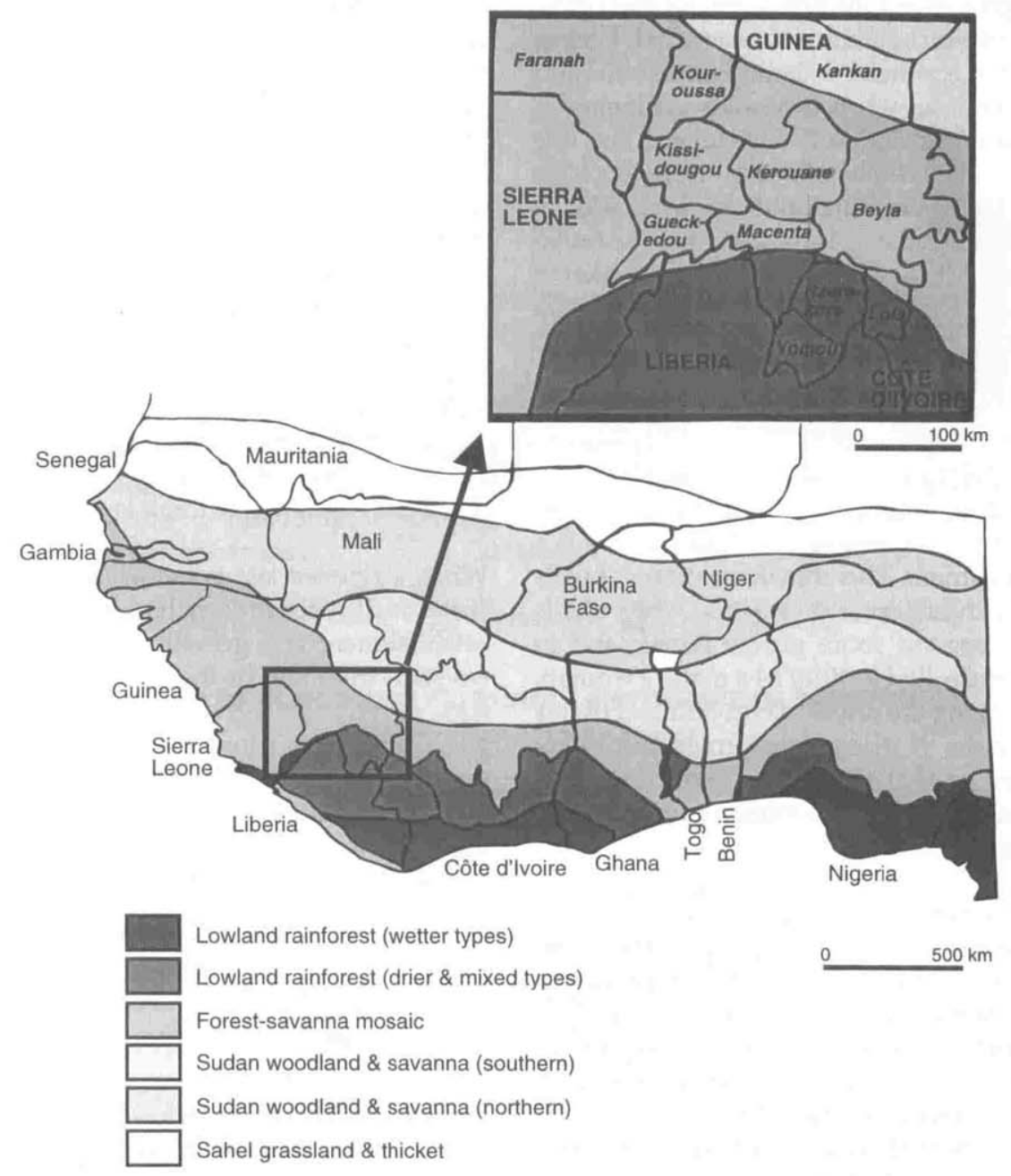

\section{Based on the UNESCO/AEFTAT/UNSO Vegetation Map of Africa}

residues of processed harvests, gathered products and cooking. Much of the land would once have been covered by gardens, whether between the houses and kitchens, or extending out from them into the settlement margins.

Habitation and gardening, farmers suggest, transform soils, making them more workable and productive. 'New' savanna land (dukura) which has never been cultivated tends to be hard, and when it rains the water tends to run off the surface rather than infiltrating into it. Butgardens are dug and mounded year after year. This 'opens' the soil, villagers say, so water can enter. Organic matter from weeds, crop residues and everyday wastes is repeatedly dug into the soil, enriching it and improving its texture. Over the years, soils mounded in this way become 'oily' (tulu), and 'mature' or 'ripe' (mo); they are softer and easier to hoe, have good infiltration, and because they encourage deeper plant rooting and remain 
damp for longer, allow crops better to resist dry periods. Farmers find that the soil of old habitation sites maintains these qualities long after the site is abandoned.

While soil improvement through opening and ripening is associated with habitation sites and their kitchen gardens, it is not confined to them. Farmers suggest that regular farming, when it mimics gardening in repeated mounding and soil enrichment, has the same effect. For example planting crops such as cassava, peanuts, fonio, maize and okra in rotation in savanna might ripen the soil after 3-4 years. Kuranko farmers say a place so treated 'will become like an abandoned site' ( $a$ di ke tombondu di), using tombondu as a powerful metaphor for the result of soil change.

For Kuranko, soil ripening is not just an irreversible change in the soil, but also a categorical change in people's relationship to that place. In effect, through work new land is 'initiated' into a mature, safe and productively fertile status, of which its oiliness is a physical embodiment. This transformation parallels that at a girl's initiation and excision, when she is considered to become more purely female and to acquire safe, controlled fertility as a mature woman, oiliness again being the physical embodiment of this transformed state. A place transformed from new land to ripened garden acquires an explicit association with female reproductive roles; a garden is nako, 'mother's business'.

Yet becoming feminine, in this sense, must be understood within the broader gender relations associated with settlement foundation and the status of patrilineal descent groups. Initiated women as wives and mothers help to consolidate and reproduce lineage status, while their 'initiated' gardens consolidate its settled place and territorial identity. Tombondu, whether real or metaphorical, becomes and remains tenurially distinct, controlled by the patrilineal descent group whose members first worked there, in contrast with unimproved savanna land tenured at the village level. Many old village and hamlet sites are identified with a silk cotton, baobab or mango tree planted by a senior member of their founding patrilineage. From a patrilineal point of view Kuranko see such tree planting as central to the process of land maturation: definitional, not merely indicative, of it.

The transformation of dukura to tombondu has an important effect on vegetation cover. When left fallow, ripened soils tend to develop a dense woody vegetation (yeren) which, over time, becomes semideciduous forest $(t u)$. In effect, savanna successions associated with the farm-fallow cycles on new soils are 'deflected' to forest successions which endure through subsequent fallow cycles. According to farmers this is for several reasons. Tree seeds germinate and establish well on the opened, softer, more homogeneous soils which are less prone to drought; explanations supported by recent ecological studies of soil and vegetation potential in the forest-savanna mosaic (e.g. Casta et al. 1989; Avenard et al. 1972; Moss and Morgan 1977). Fire is less intense since the highly flammable tall, dense grass Andropogon gayanus associated with new soils is eliminated during the cultivation sequences and does not immediately reinvade. It is replaced by shorter grasses such as Pennisetum violaceum and Hyparrhenia sp. which provide less fuel. Furthermore these species are particularly palatable to domestic and wild herbivores, which reduce fire fuel still further by grazing and trampling when they congregate there in the dry season.

When a ripened site is fallowed, its improved soil, water and fire conditions therefore facilitate the rapid establishment and growth from seed of semi fireresistant trees and bushes. With time, these species such as Albizzia zygia, Entada africana and Ficus gnaphralocarpa, are joined by and eventually cede to the range of trees characteristic of forest formations. A stark vegetation boundary thus appears between the more or less open savanna on new land, and the dense woodland - ultimately grassless forest - on tombondu. Vegetation surveys which we carried out across tombondu-dukura boundaries show up this distinction (Figure 2), although their full results are beyond the scope of this article. Villagers commonly read the striking visual distinction between forest and savanna vegetation on uplands as indicative of a tombondu-dukuraboundary in landscapes with which they are not familiar, and whose specific history they do not know.

Although almost unnoticed in ecological research to date, the anthropogenic deflection of savanna to forest vegetation appears to be common throughout this part of the forest-savanna transition zone, whether as an active soil improvement strategy, or as a fortuitous side effect of particular land-use patterns. Susu farmers in Kukuna, northern Sierra Leone have told us how they can establish improved bush-fallows from savanna through combining intensive cultivation, which buries vegetation and stimulates termite activity, with cattle-grazing strategies to reduce fire 
Figure 2: Vegetation cover on tombondu and new land, Sandaya

Average number of trees by height class

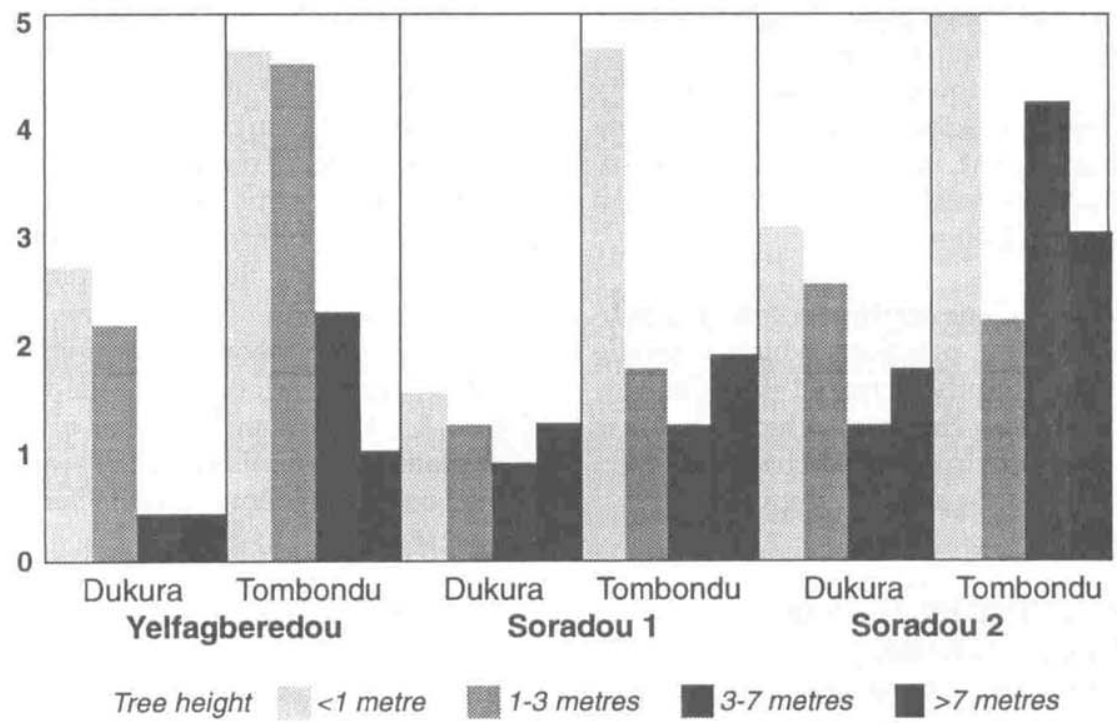

Grass cover and dominant herbaceous species

Percentage grass cover

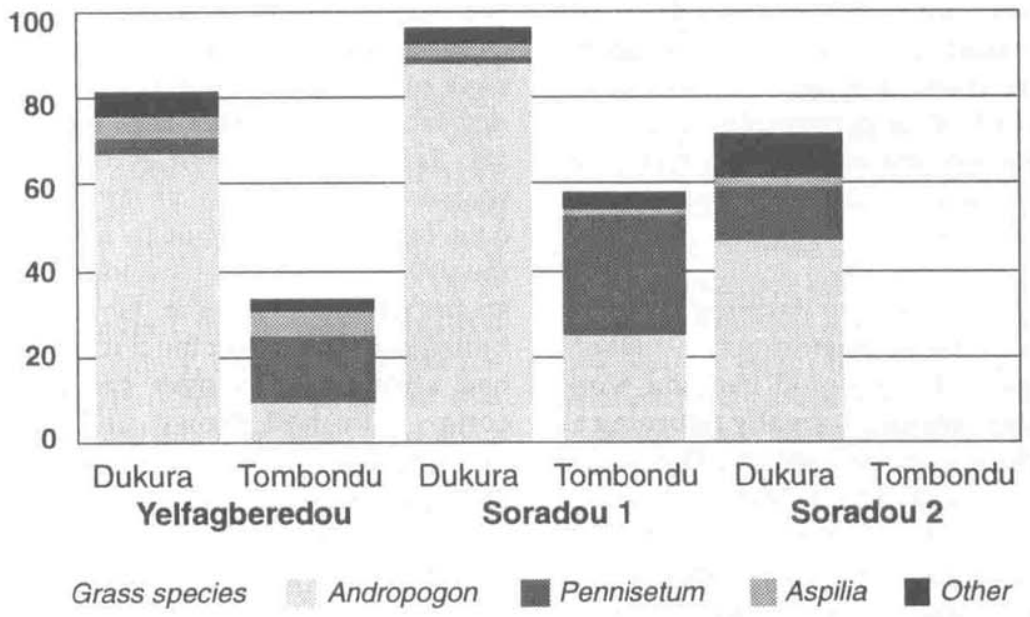

Source: Survey of a pair of adjacent sample plots of $5 \mathrm{~m} \times 40 \mathrm{~m}$, similar except for cultivation history, at three sites near Sandaya, north-west Kissidougou Prefecture: Yelfagberedou (tombondu on old farm camp, last famred c. eight years ago); Soradou 1 (tombondu on an old village site, last farned c. twelve years ago); and Soradou 2 (tombondu on old village site, last farmed $>20$ years ago). 
fuel. ${ }^{2}$ Similar methods are used by Sankaran farmers in Guinea's Faranah prefecture to establish denser, dry forest fallows dominated by Uapaca somon, locally termed somo $t u$. Such upgraded vegetation is valued largely for its improved fallow qualities for agriculture, and has more general significance in increasing the proportion of forest in the forestsavanna mosaic. Indeed these local practices severely undermine received wisdom about forest-savanna mosaic vegetation: that upland forest areas are 'natural', and that the effect of local land use on forest area is negative or at best neutral.

In many Kuranko village territories the area subjected to soil-ripening practices which upgrade vegetation has significantly increased since the midtwentieth century. The changes in local land use accounting for this environmental change depend on changing patterns of gendered resource use.

\section{GARDENING IN THE HISTORY OF GENDERED RESOURCE USE}

Soil-ripening in women's homestead gardens provides a conceptual basis for intensive land use more generally, providing a foundation from which social innovations in cropping practice have taken place in recent history. Intensively cultivated tombondu-like sites, once limited to settlement proximity, now occupy larger landscape areas, provide the main sites in which peanut, fonio and cassava production is concentrated, and are especially used by women and certain men producing food and cash within new social and economic circumstances.

In the early twentieth century farming patterns centred on wet season farming encampments where a residential compound $(l u)$ would live and work during the cultivation season, normally returning to the main village during the dry season. This living pattern had been well-suited to the demands of dry season warfare before the twentieth century, and farming in large groups provided security in the face of withdrawals of male labour, whether for war, trade or the unpredictable forced labour and taxation demands of the early French colonial regime.

The basis of subsistence then was upland rice, grown on large grass savanna fields and within land-extensive production cycles, involving 1-3 years cultivation and five or more fallow. Other crops were grown largely within these savanna rice production cycles, whether as intercrops or on second and, more rarely, third year sites. Once the men of the group had uprooted and burned fallow grasses, the site was cropped with rice and intercropped with cotton, sesame, sorghum, maize, beans, and assorted sauce ingredients. Parts of the site would be fallowed immediately after harvest, but parts - generally those nearer the farm camp, and easier to protect from animals - would be cropped for a second year with fonio, cassava and the long-duration varieties of 'small' peanut present at the time. Similar upland production cycles occasionally used gallery forests when available along streamsides and valley slopes. A little wetland rice was also produced on river plains and in inland valley swamps, the latter farmed on a long-fallow system often adjacent to the upland farm.

The compound head controlled the upland rice which provided the main food for compound members, and was prepared for the group by compound women in rotation. When compound rice was unavailable, members turned to the rice, cassava or fonio which they produced within different social arrangements; as sub-groups within the compound consisting, for example, of a man and his wives and children, or a widow and her sons. One or two days of the week were liberated from compound rice farming to enable this. Certain people could also farm on their own account. Men and senior women grew cotton as an intercrop or in its own field; women spun it, and men wove it into the strips of cloth which provided basic clothing and an important trade item. Gendered labour inputs influenced claims over the cloth product, and women had strong claims over the cloths made from cotton they had grown and spun. Wives also planted and controlled many of the other intercrops for their use in sauce preparation during their cooking turns, and some women farmed peanuts on their own account.

This pattern of upland savanna use held the vegetation within a savanna succession. The minimum tillage characteristic for upland rice, and the very superficial mounding for small peanuts, had little enduring effect on the soil and savanna grasses,

\footnotetext{
2 We are indebted to Kate Longley for providing the opportunity for these conversations within the context of her research on Susu rice farming.
} 
which would rapidly reestablish in the fallow and subsequently be maintained by the regular and intense dry season fires. Soil ripening within extended cropping sequences was largely confined to the limited areas immediately around the farm camp. Here, women made small perennial gardens (nako) to produce okra, chilli pepper, aubergines, leaves, maize, yams, sweet potato, taro and tobacco, whether for consumption or to give and exchange. Within the main village, such gardens often covered the area between the houses and the peripheral forest island. While women generally completed all the tasks for themselves, they sometimes gained help from male kin with mounding. In its individuated work pattern and product control, this gardening was socially distinct from the upland rice cycle with its compound-based labour and income claims and its large orchestrated labour groups.

Farming patterns changed noticeably from the midtwentieth century. In sum, smaller farm-households became the sole locus of rice production, itself concentrated in annually-cultivated inland valley swamps. Upland farming of other crops became more important but, no longer integrated with rice farming cycles, it became concentrated in land-intensive gardening. This transformation can be attributed to several interrelated causes.

Provisioning began to devolve onto smaller provisioning groups as new economic opportunities reduced members' economic dependence on thecompound head. From the 1940 s young men could more easily finance their own marriage payments from migrating to work in coffee production, upland farming or palm-fruit cutting further south, or in European or Independent mines and industrial plantations. Such autonomy, coupled with permanent and seasonal male outmigration, meant that farm-households became much smaller; perhaps a man who had acheived independence from his father or older brothers working only with his own wives and children, or a single remaining son working with his father. In this context, swamps became more attractive than uplands because male labour demands for clearance and cultivation did not begin until much later in the year - in July rather than April or earlier - making swamp farming compatible with extended dry season migration. Meanwhile, the pattern of farm camp residence declined as smaller farm-households made farm hamlets less viable, and people came to prefer to reside in the main village close to coffee plantations, the mosque and school.
How much rice was sold or given away as opposed to kept for food now became a matter more of conjugal strategy - of 'bargaining' between husbands and wives - than between them and higher compound authority. Men controlled rice stores, and a wife's influence over them would depend on her leverage over him, whether founded on their personal relationship, her status among co-wives, her children, or how much brideprice had been paid. Such tensions, in the context of increasing profitability for food crop sale and increasing needs for money, meant that women and younger men became interested in growing more personal food crops for their own food security or cash. Women had always had a degree of private economy, but found themselves increasingly short of produce and money for salt and stock cubes, clothing, kitchen utensils, medical expenses, and for the gifts to kin and friends at weddings, funerals and initiation ceremonies on which their support networks depended (cf. Berry 1989, Leach 1994). Equally they needed working capital for small-scale trade.

These tendencies intensified during the pre-war period when taxation forced rice sales, and were further enhanced during the wartime food requisitioning period when farmers gave up much of their rice and turned more heavily to the 'secondary' food crops such as fonio, peanuts, taro and cassava. New, higher-yielding, more rapidly-maturing peanut varieties introduced from the 1930 s particularly encouraged this. When wartime requisitioning was lifted in the 1950s coffee production replaced men's rice sales, but women still did not drop what had become for them lucrative cash crops, so higher production of these secondary crops continued. After Independence official coffee prices plummeted, rice again replaced coffee as the principal cash crop, and women again invested even more heavily in personal food production. They worked all the harder as heavy taxes were levied in cash and kind, and women were obliged to pay their way, especially if their husbands had emigrated.

Thus today many farm-households consist of a husband, wife[s], unmarried sons and daughters - perhaps with the man's aging parents - and all work on the farm-household rice field which the older man controls. At their discretion, men may also prepare a fonio or cassava crop demarcated for hunger season food. But all women, young dependent men and even older ones also arrange their personal crops. Women can farm a rice swamp in the rare case that her husband lends part of his, or a neighbour 'shows 
Table 1: Peanut, cassava, and fonio fields in Sandaya 1993

\begin{tabular}{|ccccc|} 
& Upland & Swamp & $\begin{array}{c}\text { Cassava } \\
\text { peanuts }\end{array}$ & $\begin{array}{c}\text { Fonio } \\
\text { peanuts }\end{array}$ \\
Women: only wife $(n=36)$ & 15 & 10 & 18 & 5 \\
co-wife $(n=63)$ & 27 & 20 & 28 & 13 \\
unsupported $(n=13)$ & 5 & 7 & 11 & 7 \\
Men: monogamous $(n=37)$ & 10 & 10 & 27 & 18 \\
\hline polygamous $(n=29)$ & 4 & 4 & 17 & 13 \\
\hline
\end{tabular}

pity', but swamp access, the need to pay male labour to cultivate and fence the swamp (unless she has an adult son), and labour bottlenecks with household rice, make this difficult. Women cultivate upland crops such as peanuts, cassava, fonio, vegetables, okra and some maize, as these are more suited to their land and labour access. Peanuts are their main cash crop, easily marketed $20 \mathrm{~km}$ away in Kissidougou with high value-to-weight ratio. These crops are also the mainstay of widows, migrants' 'widows' or levirate wives, who lack sons and therefore do not or have direct claims on rice.

During the earlier, upland rice period, secondary crops were grown as intercrops or on land the year after rice. But farm-household swamps neither support intercrops nor provide second-year sites. Women can squeeze a peanut crop into a swamp, by cultivating a short-duration variety early in the rainy season before the swamp rice is sown, but this is not enough. More importantly, then, they have incorporated these crops into different patterns of upland use based on 'gardening', suitable to the gender relations within which they are now being produced.

Women still garden behind their houses and beside rice swamps, but now also use gardening techniques to enable long cultivation sequences on other upland sites. By making mounds for peanuts and cassava, incorporating vegetation and other residues, breaking the mounds for fonio, and intercropping okra, beans and maize in these rotations, they can extend cropping for up to ten years, perhaps interspersed with short one year fallows. This usefully eliminates coppicing tree species which otherwise compete with the crops and whose roots make hoeing difficult. Most significantly, however, long sequences minimize male labour inputs by avoiding annual clearance, leaving women to pay only the male labour for mounding. Indeed it is generally male labour, difficult for women to access, which limits their farming. Older women may have a son to assist, but even for their husband's input most have to pay, whether in cash by the day or through other arrangements such as partial repayment for a past loan of rice. And young men may be unwilling to work even for the money, fixed as it is by village elders at a very unremunerative rate. Understandably, then, women are opportunistic in finding sites which require minimal clearance or mounding, and while they turn to second year gallery forest sites when available, they otherwise focus on long-cropped land, even for crops which might yield better on 'new land'.

For these extended cropping sequences, villagers today like to congregate in large groups, and they do this on the improved soils of tombondu sites,

\section{Table 2: Types of tombondu}

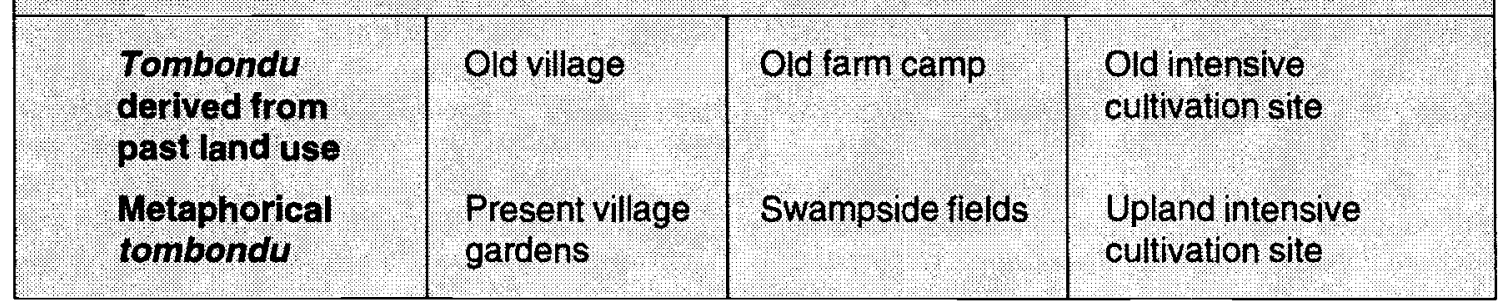


whether an abandoned village, farm camp, or a past intensive farm site.

Grouping fields is useful for pest control, socializing and casual labour-sharing arrangements. Farmers are thus managing their own fields, but within loosely-knit groups assembled from across the village, consisting of assorted female and a few male neighbours, kin, friends and strangers; a fundamentally different pattern from the patrilineally-based compound groups of the past. Farmers shift between tombondu sites as a looselyconstituted group, farming a given area until either it is no longer productive, or when neighbours have moved on. Once abandoned, tombondu soils tend to redevelop their woody vegetation.

There are strong contrasts in the ways that people consider their entitlement to farm these old tombondu sites. Male and female elders of established lineages tend to associate tombondu with the families which initiated them and lived or worked there, considering the patrilineal descendants of these families as their present land holders. From this perspective, tombondu sites are islands of lineage tenured land within territory otherwise under broader village control. To use tombondu, they suggest, one should in principle seek the authorization and benediction of the landholders, although in practice this seems to be done only rarely. The association of particular sites with particular families is not always consistent, not only because site histories become ambiguous with time but also because they can be reworked to suit present-day lineage politics. However minimal their practical tenurial importance, these associations with lineage origins provide an explicitly historical conception of tombondu - what defines it and what distinguishes it from other land.

Others - notably many women - do not consider tombondu status in these historical terms, and seem unconcerned about their settlement origins. Indeed in-married women sometimes do not even know them. They tend to distinguish tombondu from other land in more immediate agro-ecological terms, as 'land good for peanuts'; and use a tombondu site just as they would any other village land, without contacting a landholder. While this perspective reflects wives' weak structural position in lineage affairs, it also derives from the practice of moving with others as a group to a new tombondu site. Most individual women would have no cause to negotiate with the landholders even if the move initiators had done so.
Group cultivation on old sites can lead to an extension in the area of ripened soil beyond the original space covered by the village or farm camp and its gardens, as new soils on the margins are gradually incorporated into it. A typical pattern is for young men to prepare and mound new savanna land for cassava in the vicinity of their female relatives' fields within the tombondu, and for women subsequently to use the land for peanuts or fonio. Such additional areas of improved soil, not strictly part of the tombondu considered in its historical/lineage foundation sense, nevertheless acquire its agroecological characteristics and may come to be considered as tombondu by those placing emphasis on such definitions.

Although most villages have large areas of existing tombondu, certain farmers have prefered to embark on ripening new land. This is generally for the sake of convenience; to have access to gardening soils near the village or their annually cultivated rice swamps. In so doing, they not only carve out a separately tenured upland holding, but also emphasize their own status as founders of inheritable property - and in this sense, of a line of descent. Wives rarely embark on such tombondu creation on their own accounts, although they may participate in the land improvement through their own cropping within a husband's or a compound strategy. Nevertheless, in such conditions, women do see themselves as contributing to the investment and to the establishment of secure tenure over the land for their children. It is the expansion of existing tombondu sites and investment in new 'private' sites, on top of the abandonment of farm camps, which have contributed to recent increases in the area of forest successional vegetation in this part of the forest-savanna mosaic.

\section{CONCLUSIONS}

While the importance of soil-related factors in determining vegetation patterns in West Africa's forest savanna transition zone is now well recognized, the possibility that people have enabled forest establishment through edaphic manipulation is not. Yet it is precisely this possibility which is central to Kuranko experience and interpretation of ecology and landscape history.

Gardening and its ripening of soils carry conceptual associations with gender, in the complex of ideas which link oiliness, ripe productive soil and female 
fertility; and gardens with the 'mother's business' which sustains and reproduces human settlements. But one should not confuse a conceptual association such as this with women's actual impact on the environment. Neither does environmental impact depend on timeless, subsistence-focused female gardening roles within an unchanging division of labour. Rather, in this case, it depends on how soil ripening possibilities have been applied within changing patterns of gendered resource use, and it is the gender dynamics of resource use and control that help one understand these patterns of environmental change.

Despite women's role in soil-ripening, the tombondu case does not support the common argument that women's and environmental concerns are complementary. Indeed it could be argued here that the extension of soil-ripening practices reflects the intensification of resource constraints on women (limited access to swamps, second-year sites, male labour and jointly-produced income). Alleviating these constraints might constitute progressive change for women, but reduce the extent to which women engage in these 'improving' practices. But nor are women's and environmental concerns in clear conflict; Kuranko female farmers regard the greater socioeconomic autonomy linked with extended soil-ripening as positive in some respects, although ambivalently in others. As emphasized by Jackson (infra) and others, we need to escape a discourse of complementarity and conflict if we are to understand the factors and processes that mediate gendered environmental experiences, and the often contingent nature of environmental outcomes.

Kuranko find that using soils and vegetation is not anathema to caring for them, and that much everyday land use brings land improvement from their perspective. It is almost axiomatic for both men and women that unworked land will be and remain grassland savanna until brought into productivity through use. That improvement can be an inevitable consequence of use complicates analysis of agency in environmental management and investment. Some investment reflects intention; a deliberate long term soil and vegetation improvement strategy. But in other cases, 'investment' can be a spin-off of use aimed at only more immediate goals. When today's Kuranko farmers make use of the improved soil and vegetation on ancient village and farm camp sites, they take advantage of the legacy of such 'fortuitous' investment by the land's ancestors.

\section{REFERENCES}

Avenard, J.M., Bonvallot, J., Latham, M., Renard-Dugerdil, M. and Richand, J., 1974, Aspects du Contact Forêt-Savane dans le Centre et l'Ouest de la Côte d'Ivoire: étude descriptive, Abidjan: ORSTOM

Berry, S., 1989, 'Social institutions and access to resources', Africa, Vol 59 No 1: 41-55

Carney, J. and Watts, M., 1991, 'Manufacturing dissent: work, gender and the politics of meaning in a West African Society', Africa, Vol 60 No 2: 207-41

Casta, P., Chopart, J. L., Janeau, J.L., and Valentin, C., 1989, 'Mesure du ruissellement sur un sol gravillonnaire de Côte d'Ivoire après six ans de culture continue avec ou sans labour', L'Agronomie Tropicale,Vol 44 No 4: 255-262

Dankelman, I. and Davidson, J., 1988, Women and Environment in the Third World, London: Earthscan

Furley, P., Proctor, J., and Ratter, J., 1992, Nature and Dynamics of Forest-Savanna Boundaries, London: Chapman and Hall

Leach, M.,1991, 'Engendered environments: understanding natural resource management in the West African forest zone', IDS Bulletin, Vol 22 No 4: 17-24
-,1994, Rainforest Relations: Gender and Resource Use Among the Mende of Gola, Sierra Leone, Edinburgh: Edinburgh University Press for the International African Institute

Leach, M. and Fairhead, J.,1994, 'The forest islands of Kissidougou: social dynamics of environmental change in West Africa's forest-savanna mosaic', Report to ESCOR of the Overseas Development Administration, July 1994

Mies, M. and Shiva, V., 1993, Ecofeminism, London: Zed Books

Morgan, W. and Moss, R.P., 1965, 'Savanna and forest in Westem Nigeria', Africa, Vol 35 No 3: 286-293

Moss, R.P. and Morgan, W., 1977, 'Soils, plants and farmers in West Africa: Parts 1 \& 2', in J. P. Garlick and R.W.J. Keay (eds) Human Ecology in the Tropics, Symposia of the Society for the study of Human Biology, Vol XV1, London: Taylor and Francis: 27-77

République de Guinée, 1988, Politique forestière et plan d'action, Forestry policy report, Direction National des Forêts et de la Chasse, Conakry: TFAP

Watts, M. and Peet, R., 1993, 'Introduction: development theory and environment in an age of market triumphalism', Economic Geography, Vol 69 No 3 